Prace Filologiczne. Literaturoznawstwo 10(13) 2020

ISSN 2084-6045

e-ISSN 2658-2503

Creative Commons: Uznanie autorstwa 3.0 PL (CC BY)

DOI: $10.32798 /$ pflit.579

\title{
O LOCIE Z WIEŻY. HISTORIA POGGIA BRACCIOLINIEGO O KARDYNALE BORDEAUX I SZALBIERZU ORAZ OPOWIEŚĆ O KSIĘDZU, CO ZŁE WINO MIAŁ Z FACECYI POLSKICH
}

\author{
Flight from the Tower. The Story about the Cardinal of Bordeaux \\ and the Fraudster by Poggio Bracciolini and the Tale \\ "O księdzu, co złe wino miał" ["About the Priest Who Had Bad Wine"] \\ from Facecye polskie [Polish Facetiae]
}

\author{
MARTA WOJTKOWSKA-MAKSYMIK \\ Uniwersytet Warszawski, Polska \\ E-mail: m.wojtkowska-maksymik@uw.edu.pl \\ ORCID: 0000-0002-0226-8014
}

\section{Abstract}

The article concerns one of the anecdotes (II, 28) contained in the anonymous collection Facecye polskie [Polish Facetiae]. Its aim is, first, to point out the differences between the story about the cardinal of Bordeaux and the fraudster from Facetiarum liber (Confabulationum liber) by Poggio Bracciolini and the Polish text and, second, to answer the question about the source of modifications that can be found, i.a., in popular anthologies of witty stories referring to the work of Bracciolini and disseminated in Europe in the sixteenth century (mainly Die geschichte des Pfarrers vom Kalenberg and Sowiźrzat krotochwilny i śmieszny [Facetious and Funny Eulenspiegel]).

Keywords: facetiae, Renaissance, Poggio Bracciolini, translation, Schwankliteratur

\section{Streszczenie}

Artykuł dotyczy jednej z anegdot (II, 28) zawartych w anonimowym zbiorze Facecye polskie. Celem artykułu jest wskazanie różnic między opowieścią o kardynale Bordeaux i szalbierzu z Facetiarum liber (Confabulationum liber) Poggia Braccioliniego a polskim tekstem i próba

${ }^{*}$ Ukończenie prac nad artykułem było możliwe dzięki stypendium przyznanemu przez Fundację Lanckorońskich. Publikacja artykułu dofinansowana przez Uniwersytet Warszawski. 
odpowiedzi na pytanie o źródła modyfikacji, których upatrywać można m.in. w popularnych kolekcjach dowcipnych historii nawiązujących do dzieła Braccioliniego i rozpowszechnionych w Europie XVI wieku (przede wszystkim Die Geschichte des Pfarrers vom Kalenberg oraz Sowiźrzat krotochwilny i śmieszny).

Słowa kluczowe: facecja, renesans, Poggio Bracciolini, przekład, Schwankliteratur

\section{Wstęp}

Powstały prawdopodobnie w drugiej połowie XVI stulecia ${ }^{1}$, ale znany w siedemnastowiecznym wydaniu z 1624 roku zbiór Facecye polskie abo żartowne a trefne powieści biesiadne tak z rozmaitych autorów zebrane, jako też i powieści ludzkiej spisane zawiera dowcipne historie (183) o różnej tematyce i różnej długości ${ }^{2}$. Zostały one rozmieszczone w sześciu częściach („traktatach”) obejmujących - odpowiednio - „żartowne powieści” (I), teksty „o misternych kusach a fortelach” (II), „apoftegmata abo z rozumu baczne powieści” (III), „trafne przymówki i szyderstwa” (IV), rozważania „o chytrościach niewieścich” (V) i „,o głupich [...], którzy z niedomysłu co trafnego powiedzieli abo uczynili” (VI). Większość facecji czerpie, na co wskazuje zresztą długi tytuł, ze skarbca literatury powszechnej, znajdują się w nich bowiem nawiązania do utworów Waleriusza Maksymusa (Factorum et dictorum memorabilium libri novem), Giovanniego Boccaccia (Dekameron), Poggia Braccioliniego (Facetiarum liber / Confabulationum liber), Ludovica Domenichiego (Facetie e motti arguti di alcuni eccellentissimi ingegni e nobilissimi signori, 1548), Johannesa Gasta (Conviviales sermones, 1541) oraz Johanna Hulsbuscha (Silva sermonum iucundissimorum, 1568), ale także - do arcydzieł renesansowej prozy i poezji w języku polskim. I tu, wśród źródeł wielu „powieści”, wymienić trzeba Sowiźrzała krotochwilnego

\footnotetext{
${ }^{1}$ Kwestii powstania zbioru poświęcone są prace Ludwika Bernackiego (Recenzja tomu 47 BPP, „Pamiętnik Literacki” 1903, nr 2, s. 661-665), Aleksandra Brücknera (Wydawnictwa Rejowe Facecye Polskie 1624 - Znaczenie Zwierciadta 1568, „Reformacja w Polsce” 1921, nr 1-4, s. 241-257), Juliana Krzyżanowskiego (Ludovico Domenichi w „Facecjach polskich”, w: idem, Paralele. Studia porównawcze z pogranicza literatury i folkloru, Warszawa 1961, s. 105), Elżbiety Stankiewicz-Kapełuś (Z zagadnień polskiej facecjonistyki („Figliki” M. Reja - „Facecje polskie”), w: Z badań nad dawna książka. Studia ofiarowane prof. Alodii Kaweckiej-Gryczowej w 85-lecie urodzin, t. 1, Warszawa 1991, s. 117-145). W pracy Stankiewicz-Kapełuś (op. cit., s. 145), którą uznać trzeba za ostatnie tak obszerne studium dotykające problemu czasu powstania Facecyi polskich, pojawia się następująca data: 1568-1585. Dostępne do chwili obecnej wydania omawia Marina Ciccarini (cf. M. Ciccarini, Z zagadek edytorskich literatury staropolskiej - „Facecje polskie" z XVII wieku, w: eadem, Żart, inność, zbawienie. Studia z literatury $i$ kultury polskiej, tłum. M. Woźniak, Warszawa 2008, s. 90-130).

${ }^{2}$ Wydanie to stało się podstawą edycji w opracowaniu Aleksandra Brücknera (Facecye polskie z roku 1624, Kraków 1903), z którego pochodzą wszystkie zamieszczone w artykule cytaty.
} 
i śmiesznego (przed 1540), Figliki $(1562,1574)^{3}$ Mikołaja Reja i Dworzanina polskiego (1566) Łukasza Górnickiego ${ }^{4}$. Każda z facecji została również opatrzona, jak czytamy na karcie tytułowej edycji z 1666 roku, „dla snadniejszego czytelnikowi wyrozumienia" ${ }^{5}$ krótkimi, wierszowanymi sentencjami stanowiącymi rodzaj moralizującego komentarza do dowcipnych historii ${ }^{6}$, które służyć miały wyższym celom dydaktycznym: pouczeniu, przekazaniu wiedzy o tym, co właściwe i godne pochwały lub niestosowne i zasługujące na potępienie.

Trzeba tutaj nadmienić, iż taki sposób lektury facecji, piętnujących z jednej strony ludzkie wady (jak np. głupota, chciwość, skąpstwo, łakomstwo) i pozytywnie ujmujących zalety (jak np. spryt, inteligencja, zdolność do szybkiego dostosowywania się do trudnych sytuacji i niesprzyjających okoliczności), zakładał już przywoływany wyżej Poggio Bracciolini. W obszernym Confabulationum liber - zbiorze fundamentalnym dla tradycji nowożytnych antologii facecji ${ }^{7}$ zawarł on historie bardzo krótkie, przypominające apoftegmaty, i obszerniejsze, zbliżające się do nowel, po to, by ukazać zjawiska powszechnie budzące śmiech, ale i zmuszające do refleksji na temat panujących w świecie reguł (a raczej ich braku ze względu na dominującą nad ludzkim życiem ślepą Fortunę). Włoski humanista wprowadził również na karty swojego dzieła różnorodnych bohaterów: władców świeckich i papieży, wybitnych humanistów, ale także - często mieszczących się na dolnych szczeblach społecznej i majątkowej hierarchii ubogich prostaczków, wdowy i dojrzałe niewiasty obok młodych dzierlatek, nieuczciwych notariuszy i lichwiarzy... Nie inaczej postąpił autor Facecyi polskich,

${ }^{3}$ Ta, piąta i ostatnia, część Źwierzyńca opublikowana została pierwotnie pt. Opowieści przypadte, $z$ których się może wiele rzeczy przestrzedz.

${ }^{4}$ Szerzej na ten temat vide J. Krzyżanowski, op. cit., s. 104-114; E. Stankiewicz-Kapełuś, op. cit.; M. Ciccarini, Zachodnie źródta XVII-wiecznych facecji polsko-rosyjskich, w: eadem, Żart..., s. 131-155; J. Miszalska, Il lettore polacco nelle diverse epoche di fronte al „Decameron”: la problematica delle donne, w: Boccaccio e la nuova ars narrandi. Atti del Convegno internazionale di studi, Istituto di Filologia Classica, Università di Varsavia, 10-11 ottobre 2013, a cura di. W. Olszaniec, P. Salwa, Warszawa 2015, s. 153-154; M. Wojtkowska-Maksymik, Alcune tracce del „Decameron” nei „Figliki” di Mikołaj Rej, w: Boccaccio..., s. 159-170.

${ }^{5} \mathrm{Cf}$. Facecye albo funfanterye dworskie, na sześć części rozdzielone, po polsku napisane, z różnych autorów zebrane, $w$ których sie znajduja żartowne a rozkoszne przypowieści, a dla snadniejszego Czytelnikowi wyrozumienia, krótko wierszowymi sentencyami opisane i z poprawa wydrukowane, Kraków 1666. Ta edycja różni się od wydania z 1624 roku m.in. tytułem.

${ }^{6} \mathrm{Cf}$. „Starałem się, aby pod każdą przypowieścią była sentencya polska, pokazując to, jako z żartów statku uczyć się mamy"; Facecye polskie..., s. 195.

${ }^{7} \mathrm{O}$ wpływie zbioru Braccioliniego vide G. P. Marchi, Facezie del Quattrocento, w: Dizionario critico della letteratura italiana, dir. da V. Branca, a cura di A. Balduino, M. Pastore Stocchi, M. Pecoraro, t. 2, Torino 1974, s. 55-58; L. Sozzi, Le „Facezie” e la loro fortuna europea, w: Poggio Bracciolini 1380-1980. Nel VI centenario della nascita, Firenze 1982, s. 235-259; S. Altrock, Einleitung, w: eadem, Gewitzes Erzählen in der Frühen Neuzeit. Heinrich Bebels Fazetien und ihre deutsche Übersetzung, Köln-Weimar-Wien 2009, s. 1-26. 
gdzie w opowieściach o rozmaitej długości spotkać można duchownych, ziemskich właścicieli, chłopów, sprytne lub - przeciwnie - tępe żony, zmyślnych studentów, nauczycieli, przedstawicieli różnych nacji i zawodów (balwierzy, prokuratorów, kucharzy, królewskich błaznów, astrologów, bednarzy, żołnierzy...), co obrazuje powszechność ukazywanych w zbiorze zachowań, przywar bądź cnót.

\section{Facecja $O$ księdzu, co złe wino miat i jej źródła}

Doskonałym potwierdzeniem powyższych słów jest historia $O$ księdzu, co złe wino miat (II, 28) ${ }^{8}$. Zamierzam pokazać, w jaki sposób autor polskiego zbioru nawiązał do tradycji facecji humanistycznej, której początków należy szukać w Facetiarum liber Braccioliniego. Bohater interesującej nas anegdoty, chciwy ksiądz z okolic Wiednia, postanowił, korzystając z ludzkiej naiwności, sprzedać zepsute wino. Oto w lipcu („około świętej Małgorzaty”) $)^{9}$ rozwiesił w świątyniach w mieście ogłoszenie, iż będzie latał i będzie można ten cud ujrzeć na własne oczy. W wyznaczonym dniu pod kościołem od samego rana gromadził się tłum gapiów z całego Wiednia. Ponieważ słońce grzało coraz mocniej, a pleban zwlekał z wypełnieniem obietnicy, widzom zaczęło doskwierać pragnienie. Kiedy udali się do karczmy, okazało się, iż wino szybko się skończyło. Wówczas szynkarz wysłał ich do duchownego, aby odstąpił im, oczywiście za opłatą, trzymany w spiżarni alkohol. Kiedy nastał wieczór i cały trunek został wyprzedany, ksiądz, „przyprawiwszy sobie skrzydła”"10, wszedł na wieżę i

[...] jął do nich w oknie stojąc mówić: „A widaliście kiedy człowieka latającego?” Krzykną wszyscy: „Nie widali”. „Ponieważeście nie widali, i mnie też nie ujrzycie: idźcież do domu!”. Jedni księdza łajali, a drudzy się śmiali; inni go latać uczyć chcieli, ale im drogę zamknął do wieże $\mathrm{e}^{11}$.

Podobna anegdota znalazła się w Sowiźrzale krotochwilnym a śmiesznym, gdzie miast plebana mamy Sowiźrzała pragnącego zadośćuczynić żądaniu jednego z możnych mieszczan z Magdeburga. Ten bowiem rozkazał dowcipnisiowi, aby coś „nieco dziwnego a krotochwilnego [...] okazał”12. Wówczas Sowiźrzał

\footnotetext{
${ }^{8}$ Numerację facecji podaję za wydaniem Brücknera, przy czym cyfry rzymskie oznaczają numer „traktatu”, a arabskie - poszczególnych facecji.

${ }^{9}$ Facecye polskie..., s. 60 .

${ }^{10}$ Ibidem, s. 60.

${ }^{11}$ Ibidem, s. $60-61$.

${ }^{12}$ Sowiźrzat krotochwilny a śmieszny. Krytyczna edycja staropolskiego przekładu Ulenspiegla, wyd. R. Grześkowiak, E. Kizik, Gdańsk 2005, s. 42 (14. Historyja, jako Sowiźrzat w Majdeburku $z$ wieże latać chcial, a te, którzy na dziwy przyszli, z śmiechem odprawit). Dalej jako: Sowiźrzat. Szerzej na temat źródeł polskiego tłumaczenia vide H. Kapełuś, „Sowiźrzat” w polskiej tradycji ludowej, w: Literatura, komparatystyka, folklor. Księga poświęcona Julianowi Krzyżanowskiemu, red. M. Bokszczanin, S. Frybes, E. Jankowski, Warszawa 1968, s. 853-867.
} 
zapowiedział, iż zleci z wieży ratusza, a wdrapawszy się na nią, podniósł ręce i ze śmiechem zwrócił się do mieszkańców:

Mniemałem zaprawdę, żeby w świecie żadnego więcej błazna a szalonego nad mię nie było, i baczę to dobrze, że tu w tym mieście, teraz wszyscy są błaźni. Byście wy mnie byli powiedali, żeby który z was latać miał, ja bym temu był nie uwierzył, a wyście się mnie zwieść dali jako błaznowi. Jakom ja miał lecieć, gdym ani gęsią, ani żadnym ptakiem? Też żadnych skrzydeł ani piór nie mam, kromia których trudno latać. Już sami znacie, żeście zbłaźnieni ${ }^{13}$.

W opowieści o sowizdrzalskich żartach chodzi nie, jak w historii z Facecyi polskich, o potępienie chciwości duchownego, ale przede wszystkim - o wyśmianie ludzkiej naiwności, łatwowierności oraz głupoty, odbijających się w zwierciadle sprytu polskiego Tilla Eulenspiegela. Pod wpływem jego zdrowego rozsądku i zdolności do trzeźwej, a co za tym idzie - słusznej oceny każdej, a zwłaszcza absurdalnej, sytuacji zdarza się, że świadkowie jego „wygłupów” przyznają mu rację i uznają własną bezmyślność:

Ludzie, baczywszy błąd, rozeszli się. Idąc, jedni łajali, a drudzy się z tego śmiali, mówiąc jedni ku drugiemu:

- Toć błazen, ale wżdy prawdę żywą powiedział ${ }^{14}$.

Źródeł obu historii o lataniu z wieży szukać trzeba w Opowieściach uciesznych Braccioliniego, gdzie znajduje się wzmianka o krętaczu, który ogłosił, że zleci z jednej z bolońskich wież. Kiedy zeszli się ludzie, kazał im czekać cały dzień w upale i dopiero po zachodzie słońca ,pojawił się na szczycie wieży i machał skrzydłami niczym ptak, udając, że zaraz rzuci się w dół”, a następnie „odwrócił się do gawiedzi i pokazał goły zadek”15. Bracciolini, w przeciwieństwie do nieznanych nam dziś autorów Sowiźrzała i Facecyi polskich, umieszcza powiastkę na szerszym, politycznym i bardzo konkretnym tle związanym z osobą papieża Grzegorza XII. Przed konklawe miał on obiecywać, iż zakończy wielką schizmę oraz - dla uspokojenia sytuacji w Kościele i jeśli zajdzie taka konieczność - ustąpi z urzędu. Kiedy jednak zasmakował władzy, zapomniał o przyrzeczeniu, co skomentował jeden z kardynałów tak poprzez przywołanie przykładu szalbierza z Bolonii, jak i poprzez krótkie podsumowanie całego zdarzenia: „Podobnie nasz papież [...] po tylu gołosłownych obietnicach pokazał nam w końcu goły tyłek" ${ }^{16}$. Bracciolini zatem odsłonił przed czytelnikami

\footnotetext{
${ }^{13}$ Sowiźrzat, s. 42.

${ }^{14}$ Ibidem.

${ }^{15}$ P. Bracciolini, Kardynat Bordeaux i szalbierz, w: idem, Opowieści ucieszne, thum. I. Grześczak, wstęp M. Wojtkowska-Maksymik, Warszawa 2019, s. 151.

${ }^{16}$ Ibidem.
} 
mechanizmy sprawowania władzy i prawdę o zmiennej naturze wszechpotężnych, bezkarnych zwierzchników. Z drugiej strony, zdaje się między wierszami przypominać Poggio, nie byłoby ich, gdyby nie łatwowierność tych, dzięki którym sprawują rządy.

W interesującym nas fragmencie Facecyi polskich akcja toczy się jednak w pobliżu Wiednia, jej bohaterem jest duchowny, a jego celem - nieuczciwy postępek, czyli sprzedaż trunku złej jakości. Te elementy anegdoty skłaniają zaś do uważniejszego przyjrzenia się niemieckiemu utworowi pt. Die Geschichte des Pfarrers vom Kalenberg. Wydawcy Sowiźrzała krotochwilnego i śmiesznego, Radosław Grześkowiak i Edmund Kizik, wskazali ten tekst jako jedno ze źródeł opowieści o lataniu $\mathrm{z}$ wieży magdeburskiego ratusza ${ }^{17}$ (obok odpowiedniego fragmentu Facetiarum liber Braccioliniego). Zbiór historii o proboszczu z Kahlenbergu zalicza się do tzw. Schwankliteratur powstającej na obszarze Rzeszy Niemieckiej i Austrii od XIII do końca XVI stulecia ${ }^{18}$. Dzieło zostało zredagowane prawdopodobnie ok. 1470 roku przez Philippa Frankfurtera (ur. ok. 1445/50, zm. przed 1511) $)^{19}$. Ten ukrywający się też pod pseudonimem Reimer des Stoffes autor nadał opowieściom o przygodach i figlach księdza wierszowaną formę, podobnie jak uczynił wcześniej Stricker w Der Pfaffe Amis (ok.1230-1240). Utwór Frankfurtera, liczący 2180 wersów i stanowiący także jedno z wcześniejszych świadectw recepcji Confabulationum liber Braccioliniego na gruncie literatury niemieckiej, przedstawiał przygody najpierw studenta z Wiednia, a potem duchownego wysłanego przez cesarza Ottona Wesołego na parafię we wsi u stóp góry Kahlenberg (od XVII wieku nazywanej Leopoldsberg). Zresztą cesarz ten oraz biskup Passau byli świadkami albo wręcz uczestnikami przygód plebana, co pozwoliło na osiągnięcie typowego dla Schwankliteratur efektu komicznego powstającego m.in. ze zderzenia różniących się od siebie światów:

${ }^{17}$ Cf. Sowiźrzat, s. 43.

${ }^{18}$ Odnośnie do Schwankliteratur cf. (odsyłam jedynie do prac o charakterze syntetycznym): J. G. Boeckh et al., Geschichte der deutschen Literatur, Berlin 1961, s. 396-411; G. Albrecht, Einleitung, w: Deutsche Schwänke in einem Band, Weimar 1963, s. 5-25; H. Rupprich, Die deutsche Literatur vom Späten Mittelalter bis zum Barock. Erster Teil: Das Ausgehende Mittelalter, Humanismus und Renaissance, München 1970, s. 106-125. Vide Schwank, w: H. Garland, M. Garland, The Oxford Companion to German Literature, Oxford-New York 1986, s. 823; N. H. Ott, Schwank, w: Lexicon des Mittelalters, t. 7, München-Zürich 1995, szp. 1616-1618.

${ }^{19}$ Stan badań nad osobą i twórczością Frankfurtera nie jest obszerny, ale warto wymienić następujące prace: K. Bartsch, Frankfurter, Philipp, w: Allgemeine deutsche Biographie, t. 7, Lepizig 1878, s. 271-272; H. Maschek, Pfarrer vom Kalenberg, w: Die deutsche Literatur des Mittelalters. Verfasserlexicon, hrsg. von K. Langosch, t. 3, Berlin 1943, szp. 872-875; Frankfurter, Philipp, w: H. Garland, M. Garland, op. cit., s. 246; N. H. Ott, Pfaffe vom Kahlenberg, der, w: Lexicon des Mittelalters, t. 6, München-Zürich 1993, szp. 1992-1993; E. Wodarz-Eichner, Narrenweisheit im Priestergewand. Zur Interpretation des spätmittelalterlichen Schwankromans „Die geschicht und histori des pfaffen von Kalenberg”, München 2007, s. 56-66. 
dworu i jego wysokiej kultury z wsią, centrum z peryferiami, bogaczy z biedakami, mędrców z głupcami. Co ciekawe, z bohaterem literackim poematu Frankfurtera badacze łączą osobę księdza Gundackera von Thernberg (ok. 1300-1349) pełniącego obowiązki proboszcza najpierw w Kahlenbergdorf, a następnie w Prigglitz k. Gloggnitz ${ }^{20}$.

O rozpowszechnienie Die Geschichte des Pfarrers vom Kalenberg bardzo szybko zatroszczyli się drukarze; pierwsza edycja ozdobiona drzeworytami ukazała się w 1473 roku, ostatnia - w 1620, a od roku pierwodruku do końca pierwszej połowy XVII stulecia Kahlenbergerbuch wytłoczono piętnaście razy ${ }^{21}$. Potwierdzeniem popularności dzieła była nie tylko liczba wydań czy powstanie niderlandzkiej i angielskiej wersji przygód wiejskiego klechy ${ }^{22}$, ale także nawiązania do tekstu. Oprócz wspomnianego już zbioru o przygodach Tilla Eulenspiegela postać księdza z Kahlenbergu pojawiała się - zwykle jako przykład dowcipnego i sprytnego człowieka lub/i niewłaściwie zachowującego się duchownego - m.in. w epigramatach Konrada Celtisa ${ }^{23}$ czy facecjach Heinricha Bebela $(1508)^{24}$.

${ }^{20}$ Szerzej na ten temat cf. H. Maschek, Die Geschichte des Pfarrers vom Kahlenberg, „Zeitschrift für deutsches Altertum und deutsche Literatur” 1936, nr 73, s. 33-46; E. Wodarz-Eichner, op. cit., s. 126-156. O plebanie z Kahlenbergu jako postaci literackiej cf. E. Schröder, Pfarrer vom Kalenberg und Neithart Fuchs, „Zeitschrift für deutsches Altertum und deutsche Literatur" 1936, nr 76, s. 49-56.

${ }^{21}$ Powyższe dane podaję za H. Rupprich, op. cit., s. 119; V. Dollmayr, Einleitung, w: Die Geschichte des Pfarrers vom Kalenberg, hrsg. von V. Dollmayr, Halle a. S. 1906, s. V-XXXIV.

${ }^{22}$ Cf. H. Maschek, Pfarrer..., szp. 874-875.

${ }^{23}$ Cf. „Jak bardzo byłby mu miły kapłan z Kahlenbergu; / [z tych], których w jednej porze życie hołubiło, / jego grzebie zakon, któremu nazwę nadały lilie / i pole o źródłach styryjskich obfitych w wodę”, thum. I. Grześczak [„Quam bene iocundus foret huic de Monte sacerdos / Calvo: quos uno tempore vita aluit, / Coenobium hunc sepelit, dederant cui Lilia nomen / Et Campus Stiriis fontibus irriguis"]. Tekst cytuję za wydaniem: Der Briefwechsel des Konrad Celtis, ges., hrsg. und erl. H. Rupprich, München 1934.

${ }^{24} \mathrm{~W}$ zbiorze Bebela duchowny przywołany został jako przykład człowieka dowcipnego, często płatającego figle, nierzadko okrutne, innym ludziom. Cf. „Kapłan z Kahlenbergu w Austrii, którego dowcipne i zabawne powiedzonka spisano w kilku książkach, chciał pewnego razu podarować swojemu panu, księciu austriackiemu, ogromną rybę. Odźwierny nie pozwolił mu wejść, zanim tamten nie obiecał mu połowy zapłaty otrzymanej od księcia. Dlatego właśnie dowcipny kapłan, uważając chciwość odźwiernego za wstrętną, nie chciał od księcia przyjąć niczego i o nic nie prosił poza cięgami, które otrzymał bez trudu. A kiedy zasługujący na baty odźwierny nalegał nań, by oddał mu jego część, kapłan zakrzyknął: „Chętnie odstąpię ci trzy czwarte zapłaty, jedną tylko zachowując dla siebie«. I sprawił odźwiernemu solidne lanie”; tłum. I. Grześczak [,Sacerdos caecij montis in Austria, de cuius facete urbaneque dictis integri libelli perscripti sunt, cum semel principi suo duci Austriae donare vellet grandem piscem, non ante admissus est ingredi ab hostiario, quam promitteret ei mediam partem muneris a principe accepti. Quam ob causam sacerdos facetissimus quidem, hominis avaritiam exosam habens nolebat quicquam accipere a domino, nihilque aliud quam verbera expostulans, quae (cognitare) facile obtinuit. Et cum hostiarius pro sua parte caedendus astaret, clamavit ille: ego liberem pono tibi tres muneris partes, reservans mihi unam tantum, et hostiarum efflictim caedi obtinuit"]; H. Bebel, Facetiae libri tres, Tubingae, Ulrichus Mirchardus, 1544, s. 40 [Von dem Pfarhers vom Kalenberg]. 
Tytułowego bohatera Die Geschichte... wspominał też Sebastian Brant w Okręcie błaznów (1494), aczkolwiek „klechę z Kalenberku” zaliczył on do czcicieli nowego świętego - Grobiana, bardzo niebezpiecznych, bo nie tylko nieokrzesanych, lecz żyjących w grzechu i chełpiących się tym faktem:

Ten, kto się tak zacnie nosi,

Jak klecha z Kalenberku ongi

Albo jak mnich Ilsan z brodą,

Myśli: kroczę dobrą drogą.

Niejeden czyni taką szkodę,

Że gdyby to uświadczył Orest,

Który w szale stracił zmysły,

Rzekłby: mądry tak nie czyni,

Na wsi stał się ślepy może,

A to stąd, że piją chłopy ${ }^{25}$.

(LXXII, O grubiańskich błaznach)

Duchowny z okolic Wiednia pojawił się też w komentarzach Marcina Lutra do Mądrości Syracha. W glosie reformatora do apokryficznej, jego zdaniem, księgi Pisma Świętego, zawartej w wydaniu Biblii z 1545 roku (Wittenberga, Hans Lufft), postać Vicentinusa, proboszcza z Kahlenbergu, zestawiona została z Eulenspieglem. Obaj bohaterowie stanowią zresztą wyraziste przykłady zachowania piętnowanego $\mathrm{w}$ piątym wersecie $\mathrm{z}$ dziewiętnastego rozdziału. Radość z popełnianych również przez nich niegodziwości (wyrażana przecież słowami) została przeciwstawiona nienawiści do wielomówstwa:

\author{
Wer sich frewet \\ das et schalckheit treiben kan \\ der wird verachtet \\ Wer aber solche vnnütze Schwetzer hasset \\ Der verhütet Schaden ${ }^{26}$.
}

Skojarzenia przywołanych wyżej autorów, zarówno pozytywne, jak i negatywne, nie dziwią, ponieważ i o elokwencji plebana, i o jego niegodziwości czytamy w interesującym nas fragmencie Die Geschichte... (w. 423-486, il. 1), gdzie znajduje się opowieść o locie z wieży:

${ }^{25}$ S. Brant, Okręt błaznów, tłum. A. Lam, wstęp W. Dudzik, Pułtusk 2010, s. 185.

${ }^{26}$ Korzystałam z transkrypcji tekstu tego wydania dostępnej na: http://www.zeno.org (d.d. 12.06. 2019). Cf. ten fragment w Biblii brzeskiej: „Który się sobie podoba źle żywiąc, godzien jest karania, ale który się przeciwi rozkoszam, zdobi żywot swój. Który zawściąga języka swego, żywie bez trudności, a który nienawidzi wielomówności, mniej ma w sobie złości”; Biblia brzeska 1563, red. P. Krolikowski, Clifton-Kraków 2003, s. 108. 
Hie stect der pfarrer in dem glockenhau $\beta$ auff dem thure zu Kalenberg und will uber die Tunaw fliegen und het sich mit pfawenfedern umbhangen und het ein fa $\beta$ mit wein an dem berg gelegt und kam vil volcks, das do den wein außtranck [Tu stoi ksiądz w dzwonnicy na wieży w Kahlenbergu i chce polecieć nad Dunajem, i obwiesił się pawimi piórami, i postawił przy wzgórzu beczkę wina, i było dużo ludzi, którzy tę beczkę wypili] ${ }^{27}$.

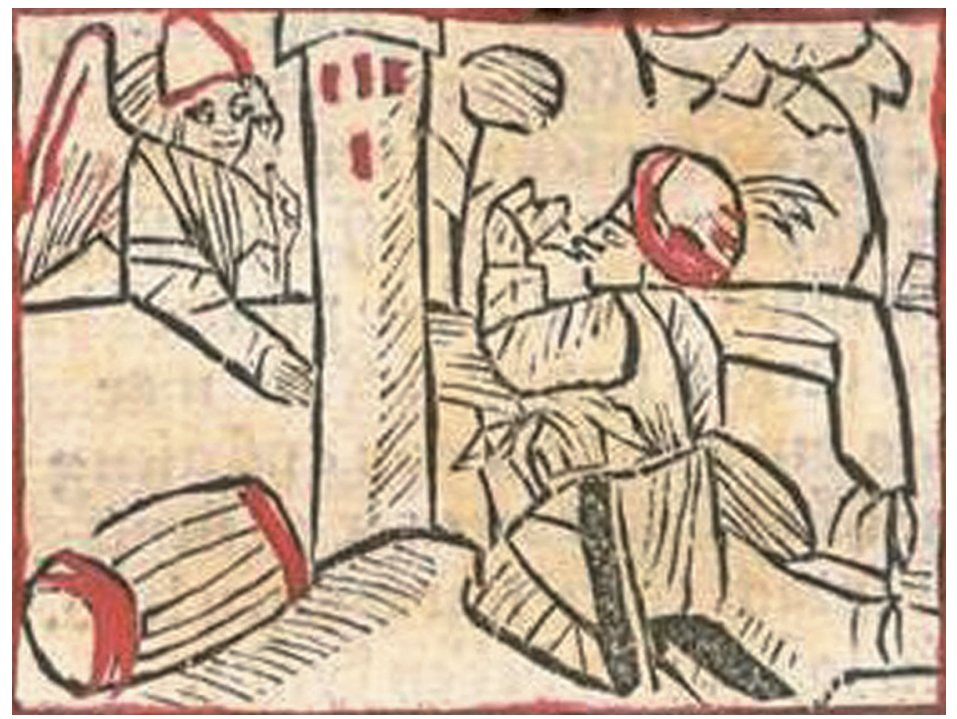

Ilustracja opowieści o plebanie z Kalenbergu z piętnastowiecznego wydania dzieła Frankfurtera (Des pfaffen geschicht vnd histori vom Kalenberg, Auch von dem aller schonsten ritter Alexander vnnd von seiner schonen frawe, Heidelberg 1490, k. $\mathrm{a}_{5} \mathrm{r}$.).

Podróż miała rozpocząć się w Kahlenbergu i zakończyć po drugiej stronie rzeki, w pobliżu Wiednia. Lot oczywiście nie odbył się, ale wieść o nim, rozpowszechniona przez proboszcza, skutecznie przyczyniła się do sprzedaży niedobrego wina. Kiedy ten cel został osiągnięty, duchowny, obwieszony pawimi piórami, pożegnał wieczorem licznych gapiów i podkreślił, iż nie zwykł fruwać w powietrzu, a do faktu zbycia zepsutego trunku odniósł się w następujący sposób (czyniąc zresztą przy tej okazji prześmiewczą aluzję do Ofiary Eucharystycznej): ponieważ chciałby być kapłanem wszystkich, będzie prosił Boga o to, aby wierni

${ }^{27}$ Niejasna jest lokalizacja wieży. W edycji Dollmayra pojawia się dzwonnica (glocken$h a u \beta)$, ale wydawca odnotowuje także inne warianty tytułu tej historii, obecne choćby we wczesnych piętnasto-, ale i szesnastowiecznych drukach, w których mowa o wieży zamkowej. Cf. choćby Des pfaffen geschicht vnd histori vom kalenberg, Auch von dem aller schonsten ritter Alexander vnnd von seiner schonen frawe, Heidelberg 1490, k. $\mathrm{a}_{5}$ r. (egz. Bibliothek Otto Schäfer w Schweinfurcie, sygn. OS 0991; druk dostępny na: https://www.digitale-sammlungen.de/ (d.d. 15.06.2019). 
wypijali więcej jego wina ${ }^{28}$. Frankfurter wspomina również, jakoby całe zdarzenie odbywać się miało podczas odpustowego jarmarku przy kościele w Kahlenbergu w bardzo gorący dzień. Być może święto to przypadało na dzień patrona parafii, św. Jerzego (23 kwietnia). Chociaż w Die Geschichte... nie znajdziemy podsumowania całej historii, to słowa proboszcza można za takowe uznać: chełpi się on własną niegodziwością, stając się nie tylko symbolem inteligentnego dowcipnisia, lecz również, jeśli nie przede wszystkim, na co wskazuje późniejsza recepcja tej postaci, niegodziwego człowieka.

Z krytycznym spojrzeniem na postać księdza mamy też, o czym już była mowa, do czynienia w Facecyach polskich, ponieważ polski autor dokonał adaptacji tylko pierwszej części dowcipnej repliki plebana (odnoszącej się do nieumiejętności latania kogokolwiek z wieży i obecnej w tej wersji opowieści zawartej już w zbiorze Braccioliniego), a historię o tym, co zdarzyło się pewnego upalnego dnia w Wiedniu (a nie w Kahlenbergu!), zestawił z jedną z najbardziej znanych anegdot o cesarzu Wespazjanie słynącym ze skąpstwa i chciwości:

Ta przypowieść zwyczaj strofuje dzisiejszych ludzi, którzy dziwnie wymysły na swe pożytki znajdują, nie dbając czasem na uczciwość, tylko aby było pożytecznie - onego sprośnego cesarza naśladując, którego gdy syn upominał, aby od kloaki czynszu nie brał, mówiąc mu, że to quaestus szarady - wyjąwszy ociec kilka czerwonych złotych, rzecze: „Synu, ale te pieniądze, choć się od kloak biorą, nie śmierdzą"29.

Skojarzenie prostego księdza $\mathrm{z}$ władcą imperium i przypisywanym mu powiedzeniem pecunia non olet wskazywać może na znajomość jeszcze jednego źródła, a mianowicie Żywotów cezarów Swetoniusza, w tym dziele bowiem Wespazjan opisany został jako człowiek, który „odznaczał się ciętym dowcipem, chociaż tak błazeńskim i plugawym, że nie cofał się przed sprośnymi wyrazami” i który dowcip ten „okazywał w swych szpetnych interesach, aby różnymi drwinkami osłabić niechęć do siebie i w żart obrócié”30.

${ }^{28}$ „Więc zobaczycie tutaj, że ja też nie będę latał; teraz jedźcie do domu w imię Boże i mówcie, że wszyscy byliście tutaj, a Bóg niech wam pozwoli wszystkim na to, że wypijecie mi więcej tego wina, o to będę Boga prosił dla was; bądźcie pewni, że chcę być kapłanem was wszystkich" [,So solt ir es auch sehen hye, / Das ich auch nit wil fliegens pflegn, / Nun fart hyn haim in gottes segn / Und sprecht, ir seit all hie geweßn, Got des laß euch all woll geneßn, / Das ir mir meer außtrinct den wein, / Des wil ich got eur pitter sein, / Des solt ir keinen zweiffel han, / Ich wil sein eur aller caplan”]; Die Geschichte..., s. 24, w. 468-476.

${ }^{29}$ Facecye polskie..., s. 61.

${ }^{30}$ Gajusz Swetoniusz Trankwillus, Żywoty cezarów, tłum., wstęp i kom. J. Niemirska-Pilszczyńska, przedmowa J. Wolski, Wrocław 1972, s. 428-429. Cf. też anegdotę o rozmowie Wespazjana z synem Tytusem o podatku od uryny (vectigal urinae): „Syn Tytus wypomniał mu, że nawet na urynę nałożył podatek. Cesarz przyłożył mu do nosa pieniądze ściągnięte jako pierwsza rata, zapytując, »czy nie razi go zapach?«. Na jego odpowiedź przeczącą rzekł: »A przecież to z uryny«"; ibidem, s. 429 [23, 3]. 


\section{Zakończenie}

Zapisana na kartach Facecyi polskich anegdota o plebanie, nieuczciwym i chciwym kłamczuchu, który dla pieniędzy nie cofnie się przed niczym, niewątpliwie świadczy o popularności opowieści o locie z wieży zawartej w Facetiarum liber Braccioliniego. Ciekawy jest jednak sposób jej opracowania, ponieważ autor (lub/i redaktor) polskiej antologii zmienia miejsce akcji (z Bolonii na Wiedeń) i bohaterów (miast bolończyków i włoskiego oszusta mamy plebana i naiwnych mieszkańców miasta nad Dunajem). Te modyfikacje upodabniają facecję $O$ księdzu, co zte wino miat do fragmentu piętnastowiecznego dzieła Frankfurtera, Die Geschichte des Pfarrers vom Kalenberg, nawiązującego do Confabulationum liber oraz chętnie czytanego i wydawanego w Europie w XVI-XVII stuleciu. Otwarte pozostaje jednak pytanie, czy twórca Facecyi polskich znał tekst austriackiego poety bądź - inaczej mówiąc - czy czytał utwór Frankfurtera, wersja polska bowiem pozbawiona jest wielu istotnych szczegółów: od nazwy rzeki i wsi Kahlenberg, przez pojawiające się w historii Frankfurtera pawie pióra oraz przykościelny jarmark, aż po szczegóły samego lotu, podczas którego - co podkreślają wersje niemieckie - duchowny chciał przemieścić się z jednego brzegu Dunaju na drugi. Fragment z Facecyi polskich zdaje się koncentrować w zasadzie nie tyle na locie, ile na postaci i postępku księdza, na co wskazuje tytuł facecji i kończące ją zestawienie wiejskiego klechy z rzymskim cesarzem, nieobecne zarówno u Poggia, jak i u Frankfurtera. Miało ono zwracać uwagę na powszechność ludzkiego zepsucia (źli i chciwi są przecież zarówno prostaczkowie, jak i możni tego świata) oraz przypominać, iż mimo upływu czasu ludzka niegodziwość nie przemija i nie zna granic, a z powodu starań o to, co i tak zostanie zniszczone, człowiek przestaje zabiegać o to, co wieczne (fakt ten podkreśla zamykające facecję przysłowie: „Nie darmo mówią Polacy: Dla marnego złota / Dziurawieje cnota”31).

Reasumując, historię $O$ księdzu, co złe wino miat na tym etapie badań uznać należy za świadectwo (niezbyt wyraziste, o czym wyżej) poczytności poematu Frankfurtera i upowszechnienia się typowych dla tego utworu wątków, zakorzenionych jednak w źródłach starszych, w tym wypadku w Facetiarum liber Braccioliniego. Świadectwo to, z pewnością wymagające dalszych i szczegółowych badań, potwierdza jednakowoż, iż dla autora polskiego zbioru istotne były nie tylko źródła włoskie, z antologią Braccioliniego na czele, ale także niemieckie, do Confabulationum liber chętnie zresztą nawiązujące ${ }^{32}$. W sprawie przyczyn obecności podobnych anegdot w różnych tekstach warto zacytować słowa Elżbiety Stankiewicz-Kapełuś, która, tropiąc wzajemne zależności między Figlikami Reja a Facecyami polskimi, zauważyła:

${ }^{31}$ Facecye polskie..., s. 61.

${ }^{32}$ Wskazywał na to już A. Brückner (cf. A. Brückner, Przedmowa wydawcy, w: Facecye polskie, s. 15-24), a po nim - E. Stankiewicz-Kapełuś (op. cit.). 
[...] powtarzanie wzajemnych anegdot [...] na ogół nie jest skutkiem wzajemnego zapożyczania, świadczy natomiast o zupełnie innym zjawisku, o popularności takich właśnie motywów w XVI wieku i wyznacza rysy pewnego rodzaju mody literackiej. [...] Stąd niektóre anegdoty występują w dwóch, trzech lub czterech prawie współczesnych sobie wersjach ${ }^{33}$.

Stankiewicz-Kapełuś przypominała również o wpływie „tradycji ustnej”34 na ostateczny kształt facecji, czego w odniesieniu do opowieści $O$ księdzu, co złe wino miał wykluczyć nie można, zwłaszcza mając w pamięci koniec tytułu całego zbioru gromadzącego przecież dowcipy „z rozmaitych autorów zebrane, jako też i powieści ludzkiej spisane”. Trzeba wreszcie zwrócić uwagę na dwie typowe dla nowożytnych facecji cechy, a mianowicie ich uniwersalność i pojemność znaczeniową. Dzięki nim - i tu warto przywołać sąd Juliana Krzyżanowskiego - materiał „przywoźny, ogólnoeuropejski” opatrywano „plombą czy wprost pieczątką swojskości" ${ }^{35}$ tak, by czytelnika skutecznie rozbawić i pouczyć. Docere, a nie tylko delectare, chciał także autor Facecyi polskich. Może właśnie dlatego „sceneria” większości śmiesznych historii zarysowana była nader ogólnie (zwłaszcza jeśli ich akcja rozgrywała się poza granicami Rzeczypospolitej), bohaterowie zaś pozostawali zwykle anonimowi. Odbiorca mógł ich znać z innych dzieł, zasłyszanych dowcipów; wiedział, czym się zajmują, niekiedy poznawał imię, rzadziej nazwisko, ale dane te nie miały znaczenia, gdyż protagoniści anegdot pojawiali się w nich przede wszystkim po to, aby za ich pośrednictwem można było skrytykować określoną wadę lub - przeciwnie - pochwalić zaletę. Nawiasem mówiąc, to właśnie ludzkie przywary lub cnoty uznać należy za pierwszoplanowych „bohaterów” Facecyi polskich, których karty ciaggle kryją przed badaczami wiele tajemnic.

\section{Bibliografia}

Altrock, Stephanie, Gewitzes Erzählen in der Frühen Neuzeit. Heinrich Bebels Fazetien und ihre deutsche Übersetzung, Köln-Weimar-Wien 2009.

Bartsch, Karl, Frankfurter, Philipp, w: Allgemeine deutsche Biographie, t. 7, Lepizig 1878. Bebel, Heinrich, Facetiae libri tres, Tubingae, Ulrichus Morchardus, 1544.

Bernacki, Ludwik, Recenzja tomu 47 BPP, „Pamiętnik Literacki” 1903, nr 2.

Biblia brzeska 1563, red. P. Krolikowski, Clifton-Kraków 2003.

Boeckh, Joachim G., Albrecht Günther, Klaus Böttcher, Klaus Gysi, Paul Günther Krohn, Geschichte der deutschen Literatur, Berlin 1961.

Bracciolini, Poggio, Opowieści ucieszne, tłum. I. Grześczak, wstęp M. Wojtkowska-Maksymik, Warszawa 2019.

Brant, Sebastian, Okręt błaznów, tłum. A. Lam, wstęp W. Dudzik, Pułtusk 2010.

\footnotetext{
${ }^{33}$ E. Stankiewicz-Kapełuś, op. cit., s. 143.

${ }^{34}$ Ibidem.

${ }^{35}$ J. Krzyżanowski, op. cit., s. 104.
} 
Brückner, Aleksander, Wydawnictwa Rejowe - Facecye Polskie 1624 - Znaczenie Zwierciadta 1568, „Reformacja w Polsce” 1921, nr 1-4.

Ciccarini, Marina, Żart, inność, zbawienie. Studia z literatury i kultury polskiej, tłum. M. Woźniak, Warszawa 2008.

Der Briefwechsel des Konrad Celtis, ges., hrsg. und erl. H. Rupprich, München 1934.

Des pfaffen geschicht vnd histori vom Kalenberg, Auch von dem aller schonsten ritter Alexander vnnd von seiner schonen frawe, Heidelberg 1490.

Die Geschichte des Pfarrers vom Kalenberg, hrsg. von V. Dollmayr, Halle a. S. 1906.

Facecye albo funfanterye dworskie, na sześć części rozdzielone, po polsku napisane, $z$ różnych autorów zebrane, $w$ których sie znajdują żartowne a rozkoszne przypowieści, a dla snadniejszego Czytelnikowi wyrozumienia, krótko wierszowymi sentencyami opisane i zoprawa wydrukowane, Kraków 1666.

Facecye polskie z roku 1624, wyd. A. Brückner, Kraków 1903.

Gajusz Swetoniusz Trankwillus, Żywoty cezarów, tłum., wstęp i kom. J. Niemirska-Pilszczyńska, przedmowa J. Wolski, Wrocław 1972.

Garland, Henry, Mary Garland, The Oxford Companion to German Literature, Oxford-New York 1986.

Günther, Albrecht, Einleitung, w: Deutsche Schwänke in einem Band, Weimar 1963.

Kapełuś, Helena, „Sowiźrzał” w polskiej tradycji ludowej, w: Literatura, komparatystyka, folklor. Księga poświęcona Julianowi Krzyżanowskiemu, red. M. Bokszczanin, S. Frybes, E. Jankowski, Warszawa 1968.

Krzyżanowski, Julian, Ludovico Domenichi w „Facecjach polskich”, w: idem, Paralele. Studia porównawcze z pogranicza literatury i folkloru, Warszawa 1961.

Marchi, Gian Paolo, Facezie del Quattrocento, w: Dizionario critico della letteratura italiana, dir. da V. Branca, a cura di A. Balduino, M. Pastore Stocchi, M. Pecoraro, t. 2, Torino 1974.

Maschek, Hermann, Die Geschichte des Pfarrers vom Kahlenberg, „Zeitschrift für deutsches Altertum und deutsche Literatur" 1936, nr 73.

Maschek, Hermann, Pfarrer vom Kalenberg, w: Die deutsche Literatur des Mittelalters. Verfasserlexicon, hrsg. von K. Langosch, t. 3, Berlin 1943, szp. 872-875.

Miszalska, Jadwiga, Il lettore polacco nelle diverse epoche di fronte al „Decameron”: la problematica delle donne, w: Boccaccio e la nuova ars narrandi. Atti del Convegno internazionale di studi, Istituto di Filologia Classica, Università di Varsavia, 10-11 ottobre 2013, a cura di W. Olszaniec, P. Salwa, Warszawa 2015.

Ott, Norbert H., Pfaffe vom Kahlenberg, der, w: Lexicon des Mittelalters, t. 4, München-Zürich 1993, szp. 1992-1993.

Ott, Norbert H., Schwank, w: Lexicon des Mittelalters, t. 7, München-Zürich 1995, szp. 1616-1618.

Rupprich, Hans, Die deutsche Literatur vom Späten Mittelalter bis zum Barock. Erster Teil: Das Ausgehende Mittelalter, Humanismus und Renaissance, München 1970.

Schröder, Edward, Pfarrer vom Kalenberg und Neithart Fuchs, „Zeitschrift für deutsches Altertum und deutsche Literatur" 1936, nr 76.

Sowiźrzat krotochwilny a śmieszny. Krytyczna edycja staropolskiego przekładu Ulenspiegla, wyd. R. Grześkowiak, E. Kizik, Gdańsk 2005. 
Sozzi, Lionello, Le „Facezie” e la loro fortuna europea, w: Poggio Bracciolini 1380-1980. Nel VI centenario della nascita, Firenze 1982.

Stankiewicz-Kapełuś, Elżbieta, Z zagadnień polskiej facecjonistyki („Figliki” M. Reja „Facecje polskie”), w: Z badań nad dawna ksiażka. Studia ofiarowane prof. Alodii Kaweckiej-Gryczowej w 85-lecie urodzin, t. 1, Warszawa 1991.

Wodarz-Eichner, Eva, Narrenweisheit im Priestergewand. Zur Interpretation des spätmittelalterlichen Schwankromans „Die geschicht und histori des pfaffen von Kalenberg”, München 2007.

Wojtkowska-Maksymik, Marta, Alcune tracce del „Decameron” nei „Figliki” di Mikołaj Rej, w: Boccaccio e la nuova ars narrandi. Atti del Convegno internazionale di studi, Istituto di Filologia Classica, Università di Varsavia, 10-11 ottobre 2013, a cura di W. Olszaniec, P. Salwa, Warszawa 2015.

MarTa WoJTKowsKa-MaKsYMIK, adiunkt na Wydziale Polonistyki Uniwersytetu Warszawskiego. Autorka dwóch monografii: „Gentiluomo cortigiano” $i$ „Dworzanin polski”. Dyskusja o doskonałości człowieka w „Il Libro del Cortigiano” Baldassarra Castiglionego i w „Dworzaninie polskim” Łukasza Górnickiego (2007), Źródta i sposób ujęcia kwestii kobiecej godności w „O ślachetności a zacności ptci niewieściej” Macieja Wirzbięty (2017), redaktorka naukowa serii „Dawna Literatura Włoska. Studia i Źródła”, tłumaczka (m.in. Amintasa T. Tassa, Wiernego pasterza G. Guariniego). Jej zainteresowania badawcze obejmują staropolskie przekłady z języka włoskiego, teorię przekładu w XVI-XVII w., recepcję myśli neoplatońskiej w literaturze dawnej oraz polsko-włoskie związki literackie. 